Original Article

\title{
Payment for ecosystem services (PES): a holistic tool for sustainable forest management-a case study from Pakistan
}

\author{
Pagamento por serviços ecossistêmicos (PES): uma ferramenta holística para o manejo \\ florestal sustentável: um estudo de caso do Paquistão
}

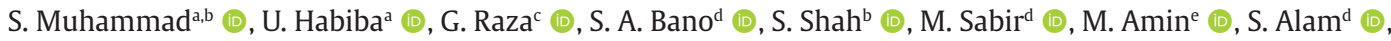 \\ A. Akhtar $^{\mathrm{f}}$ (D) and M. Hussain ${ }^{\mathrm{a}}$ (1) \\ aUniversity of Haripur, Department of Forestry and Wildlife Management, Khyber Pakhtunkhwa, Pakistan \\ bUniversity of Swat, Institute of Agriculture Sciences and Forestry, Khyber Pakhtunkhwa, Pakistan \\ cUniversity of Baltistan, Department of Biological Sciences, Skardu, Gilgit-Baltistan, Pakistan \\ dUniversity of Haripur, Department of Microbiology, Khyber Pakhtunkhwa, Pakistan \\ eShaheed Benazir Bhutto University, Department of Environmental Sciences, Sheringal, Dir (U), Khyber Pakhtunkhwa, Pakistan \\ fUniversity of Haripur, Department of Psychology, Khyber Pakhtunkhwa, Pakistan
}

\begin{abstract}
Economic valuation of ecosystem services is a new concept in forest management. Economic valuation provides basis for payment for ecosystem services (PES). Therefore, objective of this study was to evaluate eco-tourism and carbon stock services of the Maindam valley, District Swat, Pakistan. For the carbon stock calculation, a sample size of 155 plots of 0.1 hectare ( $\mathrm{Ha}$ ) was taken using preliminary survey at $95 \%$ confidence interval and $10 \%$ allowable error. The data for tourism services was collected from owners of all the hotels, 100 tourists and key informants of the area at 10\% sampling intensity on pretested questionnaire for twenty years period (1997-2017). Results showed that Miandam valley has carbon stock worth US\$16,306,000 while the value of eco-tourism was US\$ $1,578,458$ on annual basis. The results also showed that trend of tourism has drastically declined after the 9/11 incident for foreigners and locals and the situation was further deteriorated during the era of Talibanization or militancy from 2008-2011. This study recommends implementation of PES strategy at the rate of 5\%, thus a total of US\$78,922 can be earned from eco-tourism and carbon crediting in the study area annually, which could play important role in sustainable forest management.
\end{abstract}

Keywords: ecosystem services, tourism, valuation, PES, Swat, Pakistan

\begin{abstract}
Resumo
A valoração econômica dos serviços ecossistêmicos é um novo conceito no manejo florestal. A avaliação econômica fornece base para o pagamento por serviços ecossistêmicos (PES). Portanto, o objetivo deste estudo foi avaliar o ecoturismo e os serviços de estoque de carbono do vale de Miandam, distrito Swat, Paquistão. Para o cálculo do estoque de carbono, um tamanho de amostra de 155 parcelas de 0,1 hectare (ha) foi tirado, usando pesquisa preliminar com intervalo de confiança de $95 \%$ e erro admissível de $10 \%$. Os dados para serviços de turismo foram coletados de proprietários de todos os hotéis, 100 turistas e informantes-chave da área em 10\% de intensidade de amostragem em questionário pré-testado para um período de 20 anos (1997-2017). Os resultados mostraram que o vale de Miandam tem estoque de carbono no valor de US\$16.306.000, enquanto o valor do ecoturismo foi de US\$ 1.578.458 anualmente. Os resultados também mostraram que a tendência do turismo diminuiu drasticamente para estrangeiros e locais após o incidente de 11 de Setembro, e a situação se agravou ainda mais durante a era da talibanização ou militância de 2008-2011. Este estudo recomenda a implementação da estratégia de PES na taxa de $5 \%$, portanto um total de US\$ 78.922 pode ser ganho com ecoturismo e crédito de carbono na área de estudo anualmente, o que pode desempenhar um papel importante no manejo florestal sustentável.
\end{abstract}

Palavras-chave: serviços ecossistêmicos, turismo, avaliação, PES, golpe, Paquistão.

\section{Introduction}

A wide range of services are provided by natural ecosystems (De-Groot et al., 2012) which provide a dependence for life on earth (Mooney et al., 1997). The four

main categories of ecosystem services include provisioning services, regulating services, supporting services and cultural services (Capistrano et al., 2005). Economic value

*e-mail: majid@uoh.edu.pk

Received: 27 Nov. 2020 - Accepted: 14 Jan. 2021 
of these services is mostly ignored due to lack of proper mechanism for economic valuation (Blanc et al., 2018). In 1997, a debatable article was published called "The value of the world's ecosystem services and natural capital." The article extrapolated the data and came up with the economic valuation of the global ecosystem as 33 trillion US dollars (De Groot et al., 2002). Likewise, Millennium Ecosystem Assessment (MEA) report in 2005 identified and assessed 24 various ecosystem services (MEA, 2004). Several conservation schemes such as species banking, biodiversity offsets, watershed protection payments (Canada and Mariottoni, 2016) forest carbon markets, and mitigation banking, particularly REDD+ (Reducing Emissions from Deforestation and forest Degradation) comes under payment for ecosystem services (Blanc et al., 2018; McFarland, 2018). Valuation of ecosystem services is recent innovation getting importance and attracting attention of the researchers in developed and developing countries of the world (Bhatta et al., 2014). Valuation provide basis for payment for ecosystem services (PES) to encourage and enhance these services through the attention of policy makers (Defra, 2007).

The capacity to ascertain financial estimation of the ecosystem services is progressively perceived as a vital condition in leadership, reasonable business practices, and land-utilization arranging at numerous geographic scales and socio-political levels (Vo et al., 2012). The valuation or tagging price to these services is very important to convey the message of monetary value of these services to policy makers. Such communication of monetary values will enable policy makers to allocate funds for those areas where more protection, management and conservation measures are required at low cost (Crossman et al., 2011). The conversion of one hectare of forest plantation to oil palm plantation gives more income (yielding net present values of US $\$ 3,835-\$ 9,630$ ) to the owners than for protection and management for carbon credits (US \$614-\$994) which is still based on voluntary market. The same could be profitable if compliance market strategy is adopted for uniformity of the rate of carbon credits (upto US \$6,605) (Butler et al., 2009; Groot et al., 2010). Margalla Hills National Park (MHNP), Pakistan was valuated to be worth of 23 million Pakistani Rupees (PKRs) or 8 percent of aggregate of the allocation of the government (Khan, 2004). Similarly, ecotourism in southern Africa is also a potential source for economic development, biodiversity protection, poverty alleviation and sustainable forest management (Snyman, 2017). The government of Botswana has adopted tourism as option for sustainable forestry (Mantymaa et al., 2017), alleviation of poverty and economic development which rank second to the mining industry of the country in term of contribution to the gross domestic products (GDP) (Manwa and Manwa, 2014). Moreover, it is reported that deforestation rate has been decreased in Northern Costa Rica using the PES mechanism (Daniels et al., 2010).

The aim of PES program is therefore to control and make use of market to achieve more efficient and effective environmental impacts (Bulte et al., 2008). PES is an approach based on market to deal with natural environment that remunerates the poor peoples for encouraging them to efficiently manage their land and forest resources, which are ecologically important (Rodríguez-Robayo and Merino-Pérez, 2018). However, to date, cases of PES profiting poor peoples have been constrained predominantly to specific regions of the world. Thus, around 10 to 15 million households located in developing countries may get benefits from conservation of biodiversity and ecosystem services. Likewise, the market for carbon also will benefit 25 to 50 million peoples, while protection of watershed may benefit 80 to 100 million peoples. In addition, landscape beauty will also benefit 5 to 8 million with the condition that market and payment could reach to its potential which in turn will do poverty reduction globally by the year 2030 (Milder et al., 2010). PES plans depend on motivations to initiate social change and would thus be able to be thought a market-based component for nature conservation approach (Holm, 2015; Jack et al., 2008). Recently, PES emerged as a new concept in the world for compensation and encouragement of landowners to manage their land in a better way for continuous supply and maintenance of ecosystem services (Grima et al., 2016; Martinez-Harms and Balvanera, 2012). Therefore, the present study was conducted in Miandam valley of district Swat, Pakistan. Since the last few decades, Miandam valley has made significant development in the field of eco-tourism. However, the period of Talibanization and militancy adversely affected the forestry sector which ultimately result in the decline of eco-tourism industry in this area and consequently the livelihood of locals was severely affected. Thus, objective of the present study was to evaluate selected ecosystem services i.e. carbon stock and eco-tourism of moist temperate forest and its role in sustainable forest management in Miandam valley, district Swat, Pakistan.

\section{Materials and Methods}

\subsection{Study area}

Miandam valley is situated in tehsil Khwaza Khela of district Swat, Pakistan as can be seen in Figure 1. It is situated about 54 kilometers away from Mingora city on the eastern side of river Swat. It is situated around 10 kilometers toward east from the main road leading to Bahrain and Kalam. The altitude of Miandam is almost 2000 meters, however this altitude varies with place to place in the valley. The area comes under moist temperate region in climatic classification. The dominant forest species are Pinus wallichiana, Abies pindrow, Aesculus indica (horse chestnut), and Juglans regia (walnut) etc. The legal status of the forest is protected forest with 80:20 ratios. It means that $80 \%$ share of the income from forest resources belongs to local peoples of the area whereas $20 \%$ goes to the Government of Pakistan. The whole forest is divided into 25 forest compartments with an average area of 160 hectares. Thus, the total area of the forest becomes 4000 hectares. The area consists of two villages, named Gujjar village and the other is Swati village. About 10 tribes are residing in Miandam valley. All the above tribes have originally equal share in the forest but currently due 


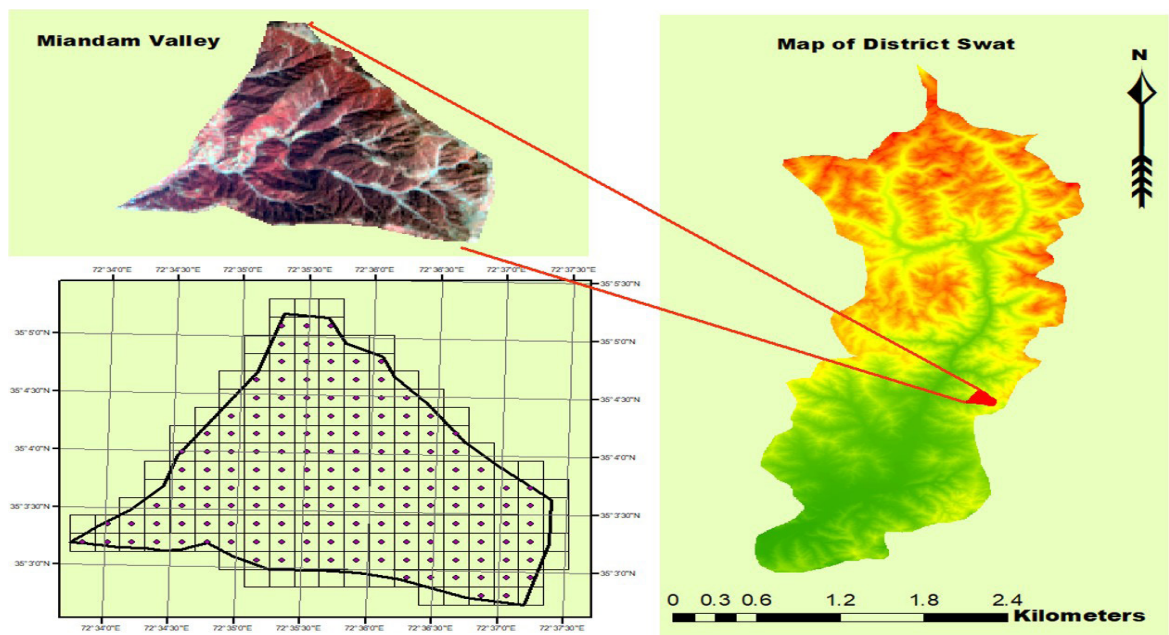

Figure 1. Location map of Miandam Valley, district Swat, Pakistan

to sale and purchase among these tribes, various tribes have now different share in the forests. Shalmani tribe is basically migrated from Shangla district and has no share in the forest at all. Shares in the forest is represented or stated by a local term called Dautar. The total forest of Miandam have been divided into 120 Dautars which has then been divided among these tribes. The Dautar was introduced during the Swat state regime (when the area was under the rule of Wali-e-Swat (King of Swat) before merge with Pakistan in 1970s) which represent shares in the developmental work for the state. The state defined various shares for the whole state in the development work and based on those shares' forests were allotted to various areas and tribes. Therefore, the whole area of Miandam valley was called Jinki Khel and 120 Dautars were allotted to this area by the Swat state. Thus, the ownership of the whole forest of Miandam valley is properly defined and designated which consequently guaranteed the best protection of the forest in this area as compared to other areas of the district Swat where most of the forests are degraded due to combined ownership and forested land disputes. Therefore, this makes Miandam valley one of the favorite spots for applying the concept of PES mechanism and its role in poverty alleviation and associated sustainable forest management, which is the ever first study on PES in Pakistan.

\subsection{Data collection and sampling design}

For valuation of carbon stock services, preliminary survey was conducted after stratification (dense, medium and open forest) to find out variation in vegetation of the study area. A total of nine random plots (three in each strata) of 17.84-meter radius were taken in dense, medium and open forest strata as summarized in Table 1. From the preliminary survey data, standard deviation and mean value was calculated in excel sheet. Then, from the standard deviation and mean, co-efficient of variation was calculated using the given equation 1 below.
Table 1. Biomass data during preliminary survey.

\begin{tabular}{|c|c|c|c|c|c|c|}
\hline District & Area & $\begin{array}{c}\text { Forest } \\
\text { Type }\end{array}$ & Strata & Aspect & $\begin{array}{c}\text { Crown } \\
\text { Cover } \\
\%\end{array}$ & $\begin{array}{c}\text { AG } \\
\text { Biomass } \\
\text { (ton/ha) }\end{array}$ \\
\hline Swat & Miandam & $\begin{array}{l}\text { Moist } \\
\text { Temp }\end{array}$ & Medium & $\mathrm{N}$ & 40 & 275 \\
\hline Swat & Miandam & $\begin{array}{l}\text { Moist } \\
\text { Temp }\end{array}$ & Medium & $S$ & 30 & 195 \\
\hline Swat & Miandam & $\begin{array}{l}\text { Moist } \\
\text { Temp }\end{array}$ & Medium & W & 30 & 120 \\
\hline Swat & Miandam & $\begin{array}{l}\text { Moist } \\
\text { Temp }\end{array}$ & Dense & E & 60 & 433 \\
\hline Swat & Miandam & $\begin{array}{l}\text { Moist } \\
\text { Temp }\end{array}$ & Dense & E & 70 & 395 \\
\hline Swat & Miandam & $\begin{array}{l}\text { Moist } \\
\text { Temp }\end{array}$ & Dense & W & 60 & 410 \\
\hline Swat & Miandam & $\begin{array}{l}\text { Moist } \\
\text { Temp }\end{array}$ & Open & S & 20 & 103 \\
\hline Swat & Miandam & $\begin{array}{l}\text { Moist } \\
\text { Temp }\end{array}$ & Open & $\mathrm{N}$ & 25 & 30 \\
\hline Swat & Miandam & $\begin{array}{l}\text { Moist } \\
\text { Temp }\end{array}$ & Open & $\mathrm{N}$ & 25 & 155 \\
\hline
\end{tabular}

$$
\begin{aligned}
& \text { Co }- \text { efficient of variation }=\frac{\text { standard deviation }}{\text { mean }} \times 100 \\
& \text { Co }- \text { efficient of variation }=\frac{149.039}{235.111} \times 100 \\
& \text { Co }- \text { efficient of variation }=63.39 \%
\end{aligned}
$$

From the above equation 1 , sample size was calculated as follows using equation 2 .

Samplesizen $=\mathbf{C V} 2 \mathbf{X}$ t $2 / \mathbf{E} 2$ 
Whereas, CV represents coefficient of variation, t equals to 1.96 for $95 \%$ Confidence Interval, $\mathrm{n}$ denotes number of sample plots, E represents allowable Error 10\% (Asrat and Tesfaye, 2013).

$$
\begin{aligned}
& \mathrm{n}=(63.39)^{\wedge} 2 \mathrm{X}(1.96)^{\wedge} 2 /(10)^{\wedge} 2 \\
& \mathrm{n}=154.37 \text { Say155 sampling points }
\end{aligned}
$$

After calculation of sample size, systematic sampling was done for data collection using grids based on sample size in the study area as shown in Figure 1. The center of each grid was marked on the map and its coordinates were recorded. Global positioning system (GPS) was used to locate these sampling points in the field based on recorded coordinates. As biomass is available in forest area in three important pools i.e. above ground biomass, below ground biomass and soil organic matter. Therefore, nested circular approach was applied for data collection of trees, shrubs and soil. A circular plot of 0.1 hectare was taken having radius of 17.84 meter. Diameter and height of all the trees were measured with calliper and haga altimeter respectively. Tree biomass was calculated using regression model developed by Ali (2017).

$$
\begin{aligned}
& \text { For Kail biomass calculation } \mathrm{M}=0.0631\left(\mathrm{D}^{2} \mathrm{H}\right)^{0.8798} \\
& \text { For Fir biomass calculation } \mathrm{M}=0.0954\left(\mathrm{D}^{2} \mathrm{H}\right)^{0.8114}
\end{aligned}
$$

Where $\mathrm{M}$ is total dry biomass, $\mathrm{D}$ is diameter and $\mathrm{H}$ is tree height

Within the same radius plot (17.84 m), 5.64-meter radius area was used for grass and shrubs biomass calculation in each tenth plot. The shrubs and grass were cut down as close to the ground as possible and weighted in the field. The vegetation contain $50 \%$ moisture so dry biomass was calculated using default value of $50 \%$ moisture in vegetation. As per IPCC guidelines (2006), 25\% biomass is found below the ground, and soil of moist temperate forest contains organic carbon up to 70 tons per hectare, so from the above ground biomass, below ground biomass was calculated for trees, shrubs and grasses. Moreover, the default value of soil carbon of moist temperate forest was taken for calculation of soil carbon. Shrubs and grasses data for biomass calculation were taken at every $10^{\text {th }}$ plot during the sampling and were generalized for remaining plots. In each plot all the three pools of carbon were added. The tree biomass contains 47\% carbon stock (Eggleston et al., 2006), so the biomass was converted into carbon stock using this 0.47 default value. The worth of stored carbon in the moist temperate forest of the study area was calculated for the whole carbon stock based on current international market price for carbon credit which is US\$ 5 as defined by the green climate fund (GCF). For calculation, the unit price of US Dollar (\$) has been taken as 125/- PKR (Pakistani rupees).

Data regarding tourism and PES was collected from the hotels and tourists while data for daily visitors was collected from key informants of the study area on pretested questionnaires. Key informants were interviewed at $10 \%$ sampling intensity. The data for tourists' inventory was collected for 20 years (1998 to 2017) from hotels and key informants. Contingent method of valuation was used as this method involves directly asking peoples in a survey, how much they would be willing to pay (WTP) for specific environmental goods or services. Due to limited number of hotels in the valley, all the hotels (13) were considered for data collection regarding the ecotourism. Around 100 tourists were also interviewed during the questionnaire survey. The questionnaire contains questions regarding the total expenses that the tourists are willing to pay, and average time of the tourists spent in the study area. Similarly, the data of daily visitors was calculated separately from the key informants along with their average daily expenses. The collected data was transferred to excel sheet for analysis and tagging price. The valuation of ecosystem services was carried out based on total expenses of tourists and their willingness to pay for ecotourism services. Similarly, socioeconomic data and contribution of ecosystem services toward poverty alleviation and forest management was collected from the key informants in the study area. The collected data was transferred to excel sheet for further analysis.

\section{Results and Discussion}

\subsection{Valuation of carbon stock}

The results for the carbon stock calculation are shown in the Table 2 using regression model $\mathrm{M}=0.0631\left(\mathrm{D}^{2} \mathrm{H}\right)^{0.8798}$. for Kail and $M=0.0954\left(D^{2} H\right)^{0.8114}$ for Fir, which indicates that the moist temperate forest of Miandam valley has an average of 151.575 tons of carbon per hectare with addition of 1.175 and 70 tons of shrub and soil carbon per hectare, respectively. Our results are in line with the IPCC recommended value of 200 tonne carbon stock per ha (IPCC, 2006). Trees act as the highest carbon pool having 152 tonne carbon stock per ha followed by soil with 70 tonne carbon stock per ha whereas shrubs and grasses accounted for less quantity of carbon stock per ha in the study area. Trees corresponded to 555 carbon credits per ha whereas soil and shrubs were accounted for 256 and 4.3 carbon credits per ha in the study area. Thus, the total carbon credits per ha were equal to 815 in the Miandam valley, Swat, Pakistan. Therefore, it is obvious from our results that if one ha of land is deforested in the study area, about 815 carbon credits in the form of $\mathrm{CO}_{2}$ can be released back into the air. Likewise, if one hectare of land is afforested/reforested, the same amount of carbon can be sequestered. The Miandam valley has a carbon stock of worth US\$ 4076.3275 per ha which has been sequestered by these moist temperate forest (Table 2 ).

Table 2. Details of total worth of carbon stock in tons per hectare and its total worth in US\$ for the study area.

\begin{tabular}{cccccc}
\hline S\# & Pool & $\begin{array}{c}\text { Carbon } \\
\text { Ton/Ha }\end{array}$ & $\begin{array}{c}\text { Credits } \\
\text { /Ha }\end{array}$ & $\begin{array}{c}\text { Price per } \\
\text { credit }\end{array}$ & $\begin{array}{c}\text { Total } \\
\text { worth }\end{array}$ \\
\hline 1 & Tree & 151.575 & 554.765 & 5 & 2773.825 \\
2 & Shrubs & 1.175 & 4.3005 & 5 & 21.5025 \\
3 & Soil & 70 & 256.2 & 5 & 1281 \\
Total & & $\mathbf{2 2 2 . 7 5}$ & 815.265 & $\mathbf{5}$ & $\mathbf{4 0 7 6 . 3 2 7 5}$ \\
\hline
\end{tabular}


Trees would contribute about $68 \%$ to the total worth from carbon credits trading, followed by soil (31\%), whereas shrubs/grasses would correspond to only $1 \%$ of the total worth of carbon credits in the study area as can be seen in Figure 2. Therefore, if the existing figure of carbon stock of the study area is taken as a baseline for REDD+ project, an additional amount of carbon can be sequestered to generate carbon credits to be sold in the international carbon credits trading market. Thus, the payments which would be received from the moist temperate forests as a REDD+ project can play a pivotal role in the poverty alleviation and sustainable forest management of the study area. However, in contrary to the above opportunity in the form of PES, forest resources in the study area are the only source of livelihood of the local community and consequently deforestation and forest degradation has been causing by the local peoples to get their basic needs of life. Milder et al., (2010) also demonstrated that the market

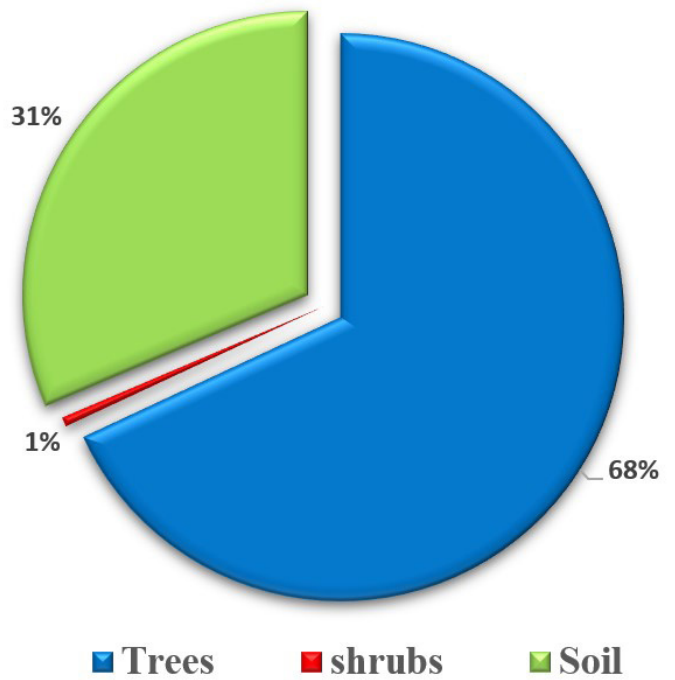

Figure 2. Percent contribution to total worth of carbon credits by the three carbon pools. for carbon will also benefit 25 to 50 million peoples in the developing countries. Awareness on the protection of forest and its worth should be communicated to decision makers to keep the importance for these forests during allocation of annual development plan (ADPs). In addition, voluntary carbon trading is now the only option to pursue and reward carbon sequestration by sustainable forestry operations (Blanc et al., 2018).

\subsection{Trend of tourists}

The data regarding trend of tourist's visit was analysed for twenty years i.e. from 1997 to 2017. The twenty years were grouped into four periods and each period was consisting of five years. ANOVA test was applied to test the null hypothesis of equal number of visitors in all these four periods. The null hypothesis of equal tourists visiting the study area is rejected as the F critical value is less than $\mathrm{F}$ tabulated value and it is concluded that the number of visitors during these four periods are not equal and showed variation as can be seen in Table 3 and Figure 3. During the first period i.e. from 1997-2001, huge number of tourists visited the Miandam valley. However, it is worth noting that during the first period 1997-2001, mostly the foreigners visited the study area. They used to stay in hotels at the Mingora city (the capital city or district headquarter of Swat) and visited recreational spots such as Miandam valley on daily basis. Similarly, during the second period i.e. from 2002-2007, the number of tourists were still on lower side and the tourists used to come to the area on daily basis. The tourists prefer to stay in the main city of Mingora and visited the area during the daytime. However, the number of tourists were drastically reduced in the third period (2007-20012) when the Taliban and militant invaded the area. The whole area of the Swat was occupied by the Taliban leadership and the writ or control of government of Pakistan was challenged. Such distressing and terrifying condition leads to a smaller number of visitors both daily basis and hostel-based in this era because of security concerns, restrictions on tourists from their family members or elders not to visit this area

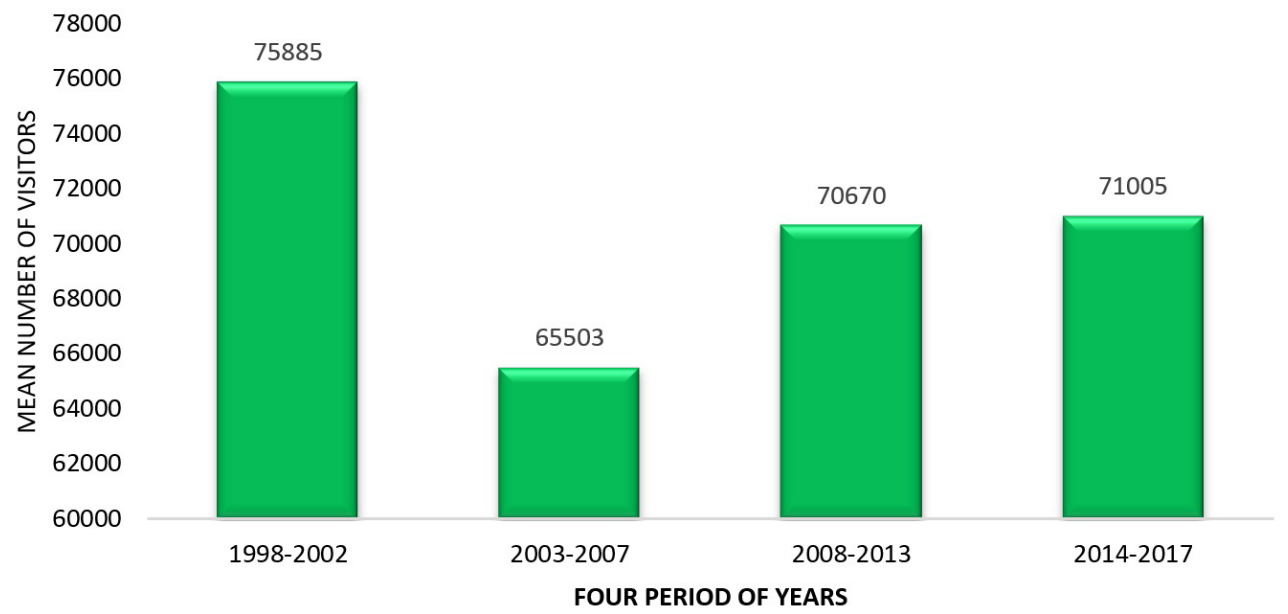

Figure 3. Showing detail of daily as well as hotel-based tourists in the study area. 
Table 3. ANOVA test for the number of visitors during the twenty years periods in the study area.

\begin{tabular}{ccccccc}
\hline $\begin{array}{c}\text { Source of } \\
\text { Variation }\end{array}$ & SS & df & MS & F & P-value & F critical \\
\hline Between Groups & 25105355583 & 3 & 8368451861 & 6.489855122 & 0.004427 & 3.23887152 \\
Within Groups & 20631466690 & 16 & 1289466668 & & & \\
Total & 45736822274 & 19 & & & \\
\hline
\end{tabular}

and then ultimately the Pakistan army did successful military operation against the insurgents in Swat. It is important to know that during this period all the hotels were occupied by the Taliban leadership for their offices in the area. During this period the hotel industry and tourism were destroyed completely in the study area particularly and Swat generally.

The fourth period (2013-2017) reflected increased number of tourists in the area. The variation in the trend of tourists can be bitterly explained that during the first period i.e. 1998-2001, mostly the foreigners used to visit the area. But due to 9/11 accident and war on terror on after that in Pakistan, the number of foreigners reduced drastically, and the tourist industry only relied only on national tourists. The last period up to 2017 has reflected increase in number of tourists due to development of hotel industry again and peace of the area. This trend is till continued and the number of tourists increases with every coming day. Our results are in line with the study conducted by Goodrich (2002) on the negative impact of war on tourism as he described the effects of 9/11 accident on tourism industry in the United State of America (USA). The author concluded that after the $9 / 11$ accident, number of visitors were declined by about 20 to $30 \%$ in the USA. Looking to this alarming situation by the hotel industry at USA, the hotels gave discount from $30-50 \%$ on theatre ticket, food, breakfast and three-night stay for two to attract the customers (Goodrich, 2002). In US states like Florida and California where tourism is major industry was completely suffered. In South Florida about 40,000 people have jobs in air lines in which 20\% (8000) were become jobless at the end of 2002 (Goodrich, 2002). Following the business strategy of US hotel industry to attract the visitors and uplift the tourism industry, the hotel industry in Miandam valley, Swat also offered various discounts such as $20-30 \%$ concession in room rent, food and other amenities to uplift the destroyed tourism industry in the study area, because $72 \%$ of the local population of Miandam valley, Swat are directly or indirectly involved in tourism related businesses such as hoteling, food huts, guiding, transport, and other services which was completely ruined after the 9/11 accident and subsequent war on terror in the study area. Furthermore, our results reflected that arrival of foreigner's visitors were completely declined which constituted $40 \%$ of the total tourists in the past before the 9/11 accident, whereas the local tourists still to visit the study area. However, tourism industry didn't get the required momentum due to security concerns specifically for the foreigner tourists in the study area. Although, Mantymaa et al., (2017) reported that the scenic and recreational quality of natural environment is a vital success factor to eco-tourism and has the potential of creating a market-based PES mechanism to promote eco-tourism in forested areas through sustainable forestry operations. Likewise, tourist's willingness to contribute to the PES scheme varies with the visitor's heterogeneity, thus, tourist's density and heterogeneity is key factor in the successful implementation of PES program (Mantymaa et al., 2017).

\subsection{Valuation of tourism}

To compare the number of daily and hotel-based tourism, student $\mathrm{T}$ test was applied. After calculation of $\mathrm{T}$ test, our null hypothesis was rejected, because the t value lies in the rejection region and it was concluded that there is significant difference between the hotel and daily based tourism. The valuation analysis for daily and hotel-based tourism on annual basis is summarized in Table 4. Summer is active season for the tourists in which more tourists are attracted to the area for the tourism due to scorching heat in other parts of the country particularly metropolitan cities in the plain areas. The results indicated that US\$ 1578458 is achieved both through daily and hotel-based tourism on annual basis in the study area which is good amount for economic development and livelihood of the local community.

The hotels management bought daily used items such as foods, papers, clothes, and other past moving consumable products from the nearby market, which indicated a major contribution of eco-tourism toward poverty alleviation in the study area, which ultimately leads to sustainable forestry because people are totally depended on these forests for their livelihood (Mantymaa et al., 2017). Likewise, the transporters of the study area are also busy in the transportation of tourists to scenic spots in the study area. The results reflected that the summer season is active season of the year where most of the tourists come to the study area. The actual reason for maximum number of tourists in the summer is associated with the hot weather condition in other parts of the country and pleasant and cold weather in the study area. The winter season reflect very low number of tourists and mostly the local peoples either migrate to lower areas for labor work or stay at homes. The winter season attract tourists toward snowfall only and peoples from lowland visit the study area just to enjoy the amazing snowfall in Miandam valley, Swat. The recent trend in the tourist's arrival to the study area anticipate greater expenditure of the local tourists and if the security situation improves for the arrival of the foreigner tourists, then the estimated figure of the present study may be doubled (Table 4 ). This amount is being spent in various ways by the tourists i.e. for local transportation to scenic spots, food items, gaining the services of guides 
Table 4. Student $\mathrm{T}$ test for number of hotel and daily based tourism at 0.05 probability.

\begin{tabular}{ccc}
\hline & Hotel based & Daily Visitors \\
\hline Mean & 23470.15 & 54188.3 \\
Variance & 422450482.6 & 1088668056 \\
Observations & 20 & 20 \\
Pearson Correlation & 0.660666703 & \\
Hypothesized Mean & 0 & \\
Difference & & \\
Degree of freedom & 19 & \\
t Stat & $\mathbf{- 5 . 5 3 9 3 6 2 9 1 7}$ & \\
$\mathrm{P}(\mathrm{T}<=\mathrm{t})$ one-tail & $1.20915 \mathrm{E}-05$ & \\
$\mathrm{t}$ Critical one-tail & 1.729132812 & \\
$\mathrm{P}(\mathrm{T}<=\mathrm{t})$ two-tail & $2.41831 \mathrm{E}-05$ & \\
$\mathrm{t}$ Critical two-tail & 2.093024054 & \\
\hline
\end{tabular}

etc. which ultimately contribute toward poverty alleviation and forest management in the study area.

Khan, (2010) applied travel cost method for the valuation of ecosystem services at Margalla Hills National Park (MHNP), Islamabad, Pakistan based on entry fee to the Park and estimated a total of 11 million PKR for the exchequer. Similarly, Lee (1997) estimated the economic value of natural based tourism in South Korea as US\$7 per visitor by using dichotomous contingent valuation mechanism per annum. Moreover, he concluded that nature-based tourism can provide business opportunities for local peoples of that area which includes breakfast business, retail shop, guiding, and transport business etc. Likewise, the present study estimated 20 US\$ per visitor using contingent method of valuation. The valuation of tourism in the study area estimated a total worth of US\$1,578,458 annually both from daily and hotel-based tourism which directly or indirectly benefit the local community of the study area. In another study Lee and Mjelde (2007) reported the tourism value of the Korean Demilitarized Zone (DMZ) and Civilian Control Zone (CCZ) between US\$ 264 and \$ 602 million. The difference between this study and our study is that Miandam area is neither protected nor untouched and exposed to human interventions. Whereas, the Korean DMZ, has no human intervention for the last half century which act as site for ecotourism and sanctuary for wildlife. Moreover, quota sampling was used in five metropolitan cities (Seoul, Daejon, Daegu, Busan, and Kwangju) while the study conducted in Miandam valley utilized random sampling approach because the area consists of only one small watershed. The purpose of both the studies was to convey the importance and economic value of the areas to policymakers. Amirnejad et al., (2006) carried out valuation of northern forests of Iran for WTP using contingent method of valuation. The annual value of these forests was estimated at US\$30.12/month for a household. The method applied in this study was similar with our study conducted in Miandam valley, Swat, however the value estimated in our study is US\$131/month for a household. The primary reason for this huge variation is more population density (more than a 1000 households) in the Miandam valley, Swat, Pakistan. Likewise, Majumdar et al. (2011) estimated mean WTP values for Savannah, Georgia, with annual value of minimum $\$ 81$ million to a maximum $\$ 167$ million from 478 tourists interviewed, however the study in our case took only 200 tourists/hotel owners for WTP. The value in our case is estimated from the average expense or income of the tourists or hotel owners, respectively while in all the above comparative studies the value has been estimated from WTP due to the reason that Miandam is place where the tourists come for either stay (30\% tourists) or on daily basis (70\% tourists) without any entry fee.

\subsection{Payment for ecosystem services (PES)}

Major portion of stakeholders are ready to pay for the ecosystem services as indicated in Figure 4. Both tourists (77\%) and key informants (84\%) showed their consent for $5 \%$ while the hotel owners agreed for $10 \%$ PES on their expense/income. The remaining stakeholders were either reluctant or did not know about the concept of PES in the study area. These stakeholders were of the view that this ecosystem is providing services which attract tourists. Therefore, they must pay for these services to sustain tourism in this area rather to deteriorate it. The tourists spare enough budget for recreational purpose to visit such spots like Miandam valley and would not be unable to make a small contribution for the development of the area in the form of PES. As, the existence and sustainability of tourism industry depend on these services of the ecosystem, so a nominal contribution by the hotel owners (10\%) and tourists (5\%) will help a lot in the sustainability of tourism, forestry and economic development of the study area. Moreover, the peoples of the area are almost poor, and this amount may also be distributed among the locals in a very transparent way who are the owners of these forests (ecosystems) and who in return will protect their forests from degradation and deforestation. However, if these owners are neglected, the efforts for improving tourism in the area will be futile exercise. The hotel owners are of the view that the hotel industry is developing in the area due to these ecosystem services. The protection and sustainable use of these ecosystem services is vital for sustainable hotel industry and forest management. Therefore, PES is very important to ensure its protection (Holm, 2015). It is worth noting that the tourists and the hotel owners who are the main stakeholders of the tourism industry in Maindham valley, Swat agreed for PES (Figure 4) and an average amount can be worked out to be implemented without complications.

As per observations of the tourists, the forest and other natural resources of the area are degrading at alarming rate as compared to earlier ages and such initiatives like PES will help a lot in the upgradation and rehabilitation of these resources. In a study conducted by Khan (2010) applied travel cost method for the valuation of ecosystem services and recreational value of Margalla Hills National Park (MHNP), Islamabad, Pakistan based on entry fee to the Park as it is the property of the Government of Pakistan. Therefore, with the imposition of Rs. 20/- entry fee, a 
total of 11 million per year was earned for the exchequer and the reason for such a huge amount was due to the reason that the tourists visit MHNP on daily basis because it is situated close to the twin cities of Rawalpindi and Islamabad. Therefore, more tourists visit the MHNP after the whole day work generally and during weekend particularly for recreation. However, in contrary to this, the tourists mostly plan their trip to Miandam valley for stay and valuation was done based on their planned expenses for the said trip. The difference between the MHNP and the present study is that the amount gained from entry fee in MHNP goes to the exchequer while the proposed amount in Miandam valley will be distributed among the local community for poverty alleviation. However, a proper and efficient mechanism should be devised to distribute this amount among the shareholders, because PES is of no use unless and until a proper, efficient and acceptable mechanism is in place to measure its natural and social impacts (Ferraro, 2011). Therefore, our study proposed a proper mechanism of $5 \%$ PES for tourists and $10 \%$ PES for hotel owner on their expenses and income, respectively as a new intervention for creation of conservation budget or its role in poverty alleviation in Maindham valley, Swat.

Similarly, the worth of carbon stock reflected the importance of these forest in the Maindham valley and cannot be claimed in the international market. However, if the same landscape is protected and consider as a baseline for the REDD+ project, huge amount of payment on additional carbon stock can be claimed in future in the international market if all the codal formalities for REDD+ are fulfilled. Moreover, as per data of the hotel and tourists, $5 \%$ payment for ecosystem services is implemented on tourism, an amount of US\$78923 can be achieved from daily visitors and hotel income which may be utilized on the development of the area and as a source of livelihood for the shareholders of the forest of the study area (Figure 5). Before 1992, the protected forests of the area were covered under proper working plan and the shareholders used to get their shares or royalties as already defined and declared by the Govt. of Pakistan. In this way, the locals were used

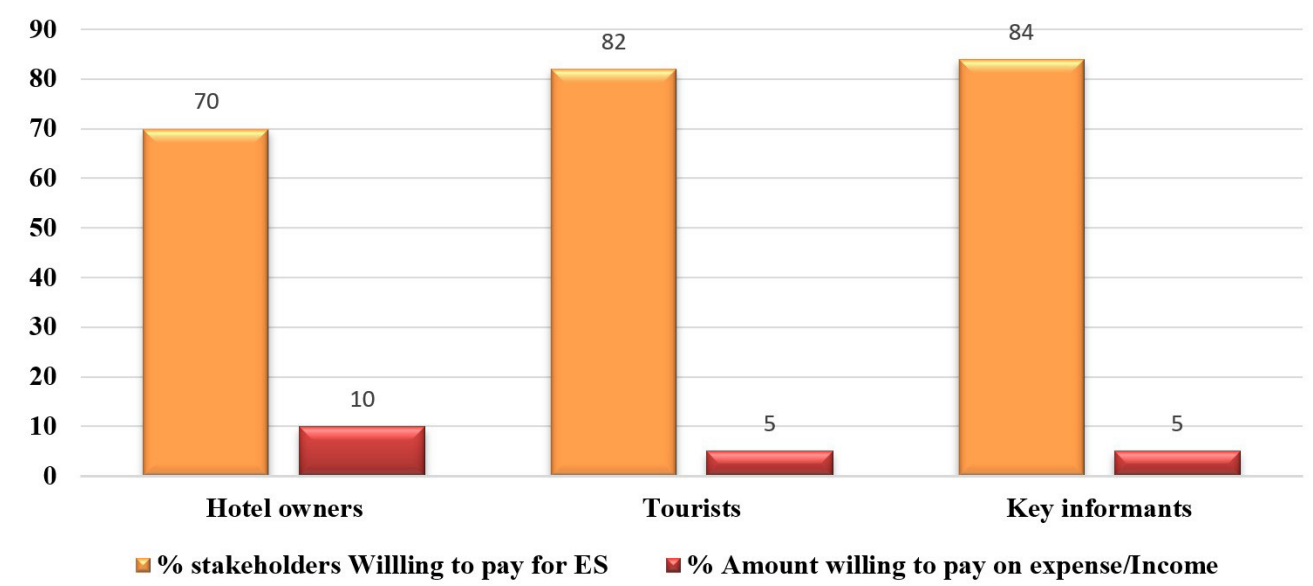

Figure 4. Details of amount of PES agreed by the stakeholders (tourists, hotels owners and key informants).

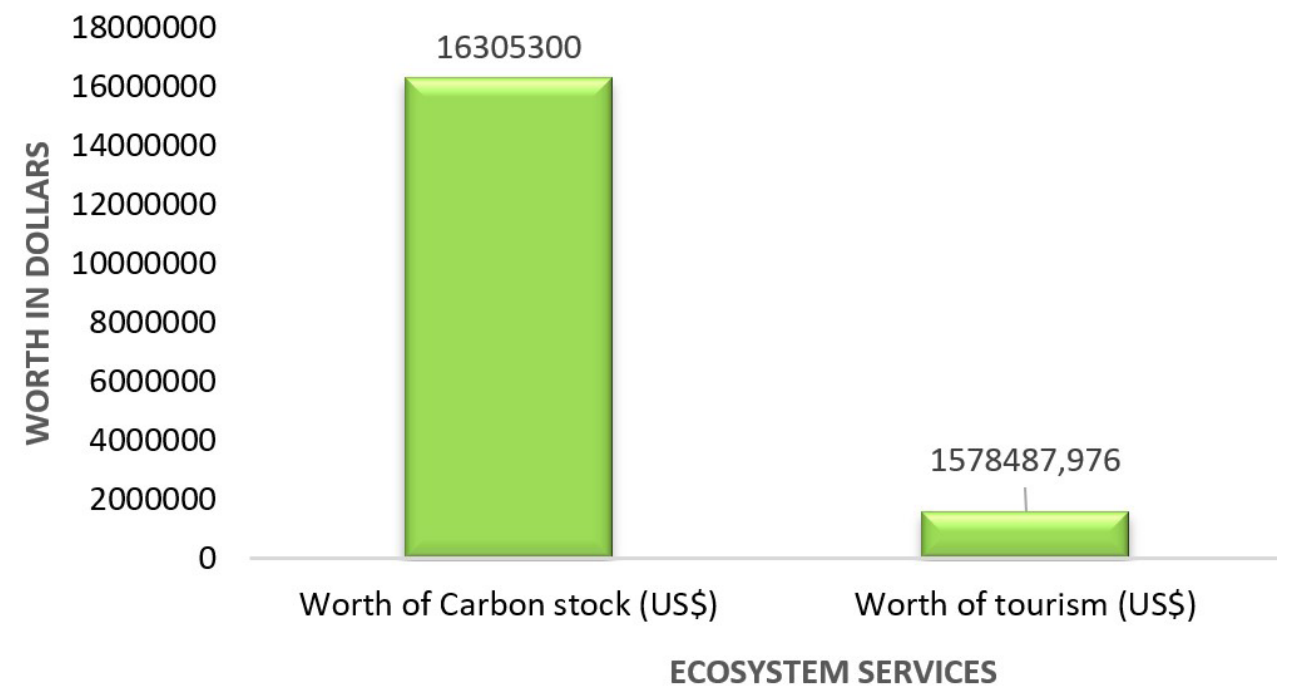

Figure 5. Monetary comparison of ecotourism and carbon stock in the study area. 
to protect their forest for their own income. However, after the ban on forest harvesting and suspension of the working plans in the country due to the inception of huge floods during 1992-1993, for which illicit forest cutting and deforestation was declared the sole source of those floods in the country, these shareholders did not get any financial benefit from these forests yet, the livelihood of whom are dependent on these forests. As a result, these shareholders cut the trees from the forests for their livelihood which ultimately leads to forest degradation and deforestation in the study area. Thus, the amount received as a PES on eco-tourism and carbon stock can compensate these deprived shareholders and will encourage them to protect their natural resources, improve their livelihood and uplift their living standards. Moreover, this study provides a baseline or benchmark for future research work on the concept of PES for other scenic and recreational areas of Pakistan, which could otherwise be degraded if did not managed on sustainable basis due to over-exploitation of forest resources by the local peoples and tourists.

\subsection{Limitations of the present study}

1. The forests in Swat is mostly protected in which local communities have legitimate shares and PES is new concept both for concerned department and shareholders who are particularly reluctant on the implementation of PES scheme as the shareholders are not satisfied with the judicious utilization of the PES income and lack of reliable mechanism in the region.

2. Due to ban on forest harvesting after the flood scenario of 1992, the local people are reluctant to give information about these resources. For getting clearer picture on these resources, the awareness on PES is necessary for the stakeholders of the study area.

3. There are some legal and institutional barriers as there is no provision in policy and forest law both at national and provincial level for implementation and operating procedure of such scheme in the country.

4. Pakistan has diverse type of ecosystem starting from mangroves to alpine pasture, providing diverse ecosystem services and therefore need a comprehensive study for implementation of PES scheme. This study only covered moist temperate forest of Miandam valley of district Swat, Pakistan.

5. Economic valuation of all the ecosystem services has not been yet carried out and without that implementation of PES scheme will not be realistic. Because economic valuation of these services will provide a base for PES scheme.

6. Pakistan is presently at Readiness phase of REDD+ and the Government of Pakistan is integrating PES with REDD+ and therefore governance and institutional arrangements for the integrated (REDD+ and PES) scheme in the ecosystems is needed.

7. This study lack information about transparent, equitable, and accountable mechanism for the disbursement of benefits to stakeholders and mechanism for conflict resolution and that the amount of benefits, the timing and the form in which these benefits are generated is based on close consultation with the stakeholders, and directly linked to actions agreed by them.

8. All the ecosystem services have not been identified by this study. There is further need to identify and evaluate other ecosystem services of the study area.

9. Due to Pakistan army operation against militants in the study area, humanitarian organization were attracted toward the study area. During this study the local expectation was the delivery of relief. In this context an inception workshop was necessary to aware the local from the findings of this study.

\section{Conclusions and Recommendations}

The purpose of this research was to find out the worth of ecotourism and carbon stock services provided by the ecosystem of Miandam valley, Swat. The results showed that the landscape of Miandam watershed has carbon stock worth $\$ 16,306,000 /$ - while the tourism services provided by this watershed is worth US $\$ 157,8458$ on annual basis. If payment for ecosystem services is implemented at the rate of $5 \%$, a total of 78922 US\$ could be secured annually for the economic development of the area. All the stakeholders are willing to pay an amount of 5\% on the income and expenditure for the poverty alleviation and development of ecotourism in the study area. Most of the peoples of Miandam area engaged in tourism related business which contribute a lot in the economic development of the study area. Thus, this research has contributed to inclusion of new aspects in forest management and protection of the forest resources in the study area. It also contributes to policy development and policy shift for forest management in Pakistan. The carbon stock of the area should be inventoried as baseline for the REDD+ project to claim payment in future on the additional carbon credits in the international markets after completing the required formalities. The present management system has been banned as a result of 1992 flood and the sole dependence of the local of the area is on forest which lead to cutting of the forest illegally causing deforestation. To control deforestation, proper management system may be implemented to fulfil the needs of the local through scientific management to prevent degradation of ecosystem services. As the owners have proper share in the proceedings of the forests which they are not receiving due to ban on harvesting, it is recommended to compensate the owners through payment for ecosystem services (PES) to achieve better protection of the resources.

To get attention of the policy makers and get proper share in the annual development planning, the worth of ecosystem services and its share in GDP may be highlighted on national level. As the study area is providing diverse type of ecosystem services, therefore, it is recommended to carried out valuation of other services to raise the importance of the area and its due share in the GDP. The hotel owners and tourists may be involved in the protection of the resources of the area through financial contribution and motivation to ensure sustainability of tourism in the study area. PES may be implemented to compensate the owners of the forest and other resources to ensure better 
management of the forest and other resources. To facilitate the tourists, tourist facilitation desk or center may be established in the study area through contribution of the hotel owners. Awareness campaign of tourists on the protection of the resources may be initiated in the study area. Awareness campaign of the local users, non-users and owners on the importance and valuation of the ecosystem services may be initiated for sustainable management of the resources. This study also recommends the formation of KPK tourism development authority to develop tourism industry in the province. The present Government of KPK has the motive to create five new recreational spots each year, it is recommended to incorporate the PES scheme for the economic development of those areas. The area with important ecosystem services should be mapped for various categories i.e. regulatory, provisioning etc. to get proper attention for its better management.

\section{Acknowledgments}

The authors would like to thank the responding hotels owners and local peoples for their participation in the questionnaire survey in the Maindam valley, district Swat, Pakistan. Any opinions, findings, conclusions, or recommendations expressed in this article are those of the authors and do not necessarily reflect the views of the contributing entities.

\section{References}

ALI, A., 2017. Biomass and carbon tables for major tree species of Gilgit Baltistan. Pakistan: Pakistan Forest Institute Peshawar.

AMIRNEJAD, H., KHALILIAN, S., ASSAREH, M.H. and AHMADIAN, M., 2006. Estimating the existence value of north forests of Iran by using a contingent valuation method. Ecological Economics, vol. 58, no. 4, pp. 665-675. http://dx.doi.org/10.1016/j. ecolecon.2005.08.015.

ASRAT, Z. and TESFAYE, Y., 2013. Forest inventory and management in the context of SFM and REDD+. Hawassa: Hawasa University. 28 p.

BHATTA, L.D., OORT, B.E.H.V., RUCEVSKA, I. and BARAL, H., 2014. Payment for ecosystem services: possible instrument for managing ecosystem services in Nepal. The International Journal of Biodiversity Science, Ecosystem Services \& Management, vol. 10, no. 4, pp. 289-299. http://dx.doi.org/10.1080/21513732.2 014.973908 .

BLANC, S., ACCASTELLO, C., BIANCHI, E., LINGUA, F., VACCHIANO, G., MOSSO, A. and BRUN, F., 2018. An integrated approach to assess carbon credit from improved forest management. Journal of Sustainable Forestry, vol. 68, pp. 23-34. http://dx.doi.org/10. 1080/10549811.2018.1494002.

BULTE, E.H., LIPPER, L., STRINGER, R. and ZILBERMAN, D., 2008. Payments for ecosystem services and poverty reduction: concepts, issues, and empirical perspectives. Environment and Development Economics, vol. 13, no. 3, pp. 245-254. http:// dx.doi.org/10.1017/S1355770X08004348.

BUTLER, R.A., KOH, L.P. and GHAZOUL, J., 2009. REDD in the red: palm oil could undermine carbon payment schemes. Conservation Letters, vol. 2, no. 2, pp. 67-73. http://dx.doi.org/10.1111/j.1755263X.2009.00047.x.
CAPISTRANO, D., SAMPER, C., LEE, M.J. and RAUDSEPP-HEARNE, C., 2005. Ecosystems and human well-being: multiscale assessments: findings of the Sub-global Assessments. Working Group of the Millenium Ecosystem Assessment. Washington, DC: Island Press. vol. 4, pp. 388-447. The Millenium Ecosystem Assessment Series, no. 4.

CANADA, C.B.D.S. and MARIOTTONI, C.A., 2016. Analysis of multicriteria in the practice of environmental services in areas of watersheds. Journal of Sustainable Forestry, vol. 35, no. 7, pp. 500-514. http://dx.doi.org/10.1080/10549811.2016.1225511.

CROSSMAN, N.D., BRYAN, B.A. and SUMMERS, D.M., 2011. Carbon Payments and Low-Cost Conservation. Conservation Biology, vol. 25, no. 4, pp. 835-845. http://dx.doi.org/10.1111/j.15231739.2011.01649.x. PMid:21507060.

DANIELS, A.E., BAGSTAD, K., ESPOSITO, V., MOULAERT, A. and RODRIGUEZ, C.M., 2010. Understanding the impacts of Costa Rica's PES: are we asking the right questions? Ecological Economics, vol. 69, no. 11, pp. 2116-2126. http://dx.doi. org/10.1016/j.ecolecon.2010.06.011.

DE GROOT, R., BRANDER, L., VAN DER PLOEG, S., COSTANZA, R., BERNARD, F., BRAAT, L., CHRISTIE, M., CROSSMAN, N., GHERMANDI, A., HEIN, L., HUSSAIN, S., KUMAR, P., MCVITTIE, A., PORTELA, R., RODRIGUEZ, L.C., BRINK, P.T. and BEUKERING, P.V., 2012. Global estimates of the value of ecosystems and their services in monetary units. Ecosystem Services, vol. 1, no. 1, pp. 50-61. http://dx.doi.org/10.1016/j.ecoser.2012.07.005.

DE GROOT, R.S., WILSON, M.A. and BOUMANS, R.M., 2002. A typology for the classification, description and valuation of ecosystem functions, goods and services. Ecological Economics, vol. 41, no. 3, pp. 393-408. http://dx.doi.org/10.1016/S09218009(02)00089-7.

DEFRA, U., 2007 [viewed 14 January 2021]. An introductory guide to valuing ecosystem services, Defra publications [online]. Retrieved from http://www.defra.gov.uk/publications/2011/03/28/ pb12852-ecosystem-services

EGGLESTON, S., BUENDIA, L. and MIWA, K., 2006. IPCC guidelines for national greenhouse gas inventories 2006. Kanagawa, JP: Institute for Global Environmental Strategies.

FERRARO, P.J., 2011. The future of payments for environmental services. Conservation Biology, vol. 25, no. 6, pp. 1134-1138. http:// dx.doi.org/10.1111/j.1523-1739.2011.01791.x. PMid:22070269.

GROOT, R.S., FISHER, B., CHRISTIE, M., ARONSON, J., BRAAT, L., HAINES-YOUNG, R., GOWDY, J., MALTBY, E., NEUVILLE, A., POLASKY, S., PORTELA, R. and RING, I., 2010. Integrating the ecological and economic dimensions in biodiversity and ecosystem service valuation. In: P. KUMAR, eds. The Economics of Ecosystems and Biodiversity: ecological and economic foundations. London: Earthscan.

GOODRICH, J.N., 2002. September 11, 2001 attack on America: a record of the immediate impacts and reactions in the USA travel and tourism industry. Tourism Management, vol. 23, no. 6, pp. 573-580. http://dx.doi.org/10.1016/S0261-5177(02)00029-8.

GRIMA, N., SINGH, S.J., SMETSCHKA, B. and RINGHOFER, L., 2016. Payment for Ecosystem Services (PES) in Latin America: analysing the performance of 40 case studies. Ecosystem Services, vol. 17, pp. 24-32. http://dx.doi.org/10.1016/j.ecoser.2015.11.010.

HOLM, S.O., 2015. A management strategy for multiple ecosystem services in boreal forests. Journal of Sustainable Forestry, vol. 34, no. 4, pp. 358-379. http://dx.doi.org/10.1080/10549811.2 015.1009633.

INTERGOVERNMENTAL PANEL ON CLIMATE CHANGE - IPCC, 2006. Agriculture, forestry and other land use. Geneva: IGES. IPCC guidelines for national greenhouse gas inventories, vol. 4 . 
JACK, B.K., KOUSKY, C. and SIMS, K.R., 2008. Designing payments for ecosystem services: lessons from previous experience with incentive-based mechanisms. Proceedings of the National Academy of Sciences of the United States of America, vol. 105, no. 28, pp. 9465-9470. http://dx.doi.org/10.1073/pnas.0705503104.

KHAN, H., 2004. Demand for eco-tourism: estimating recreational benefits from the Margalla hills national park in northern Pakistan. Kathmandu, Nepal: South Asian Network for Development and Environmental Economics.

KHAN, H., 2010. Valuing environmental services for recreation in the Margalla Hills National Park. Islamabad, Pakistan: Mountain Forum Bulletin.

LEE, C.K. and MJELDE, J.W., 2007. Valuation of ecotourism resources using a contingent valuation method: the case of the Korean DMZ. Ecological Economics, vol. 63, no. 2-3, pp. 511-520. http:// dx.doi.org/10.1016/j.ecolecon.2006.12.011.

LEE, C.K., 1997. Valuation of nature-based tourism resources using dichotomous choice contingent valuation method. Tourism Management, vol. 18, no. 8, pp. 587-591. http://dx.doi. org/10.1016/S0261-5177(97)00076-9.

MANTYMAA, E., OVASKAINEN, V., JUUTINEN, A. and TYRVÄINEN, L., 2017. Integrating nature-based tourism and forestry in private lands under heterogeneous visitor preferences for forest attributes. Journal of Environmental Planning and Management, vol. 64, pp. 724-746. http://dx.doi.org/10.1080/09640568.201 7.1333408

MAJUMDAR, S., DENG, J., ZHANG, Y. and PIERSKALLA, C., 2011. Using contingent valuation to estimate the willingness of tourists to pay for urban forests: A study in Savannah, Georgia. Urban Forestry \& Urban Greening, vol. 10, no. 4, pp. 275-280. http:// dx.doi.org/10.1016/j.ufug.2011.07.006.

MANWA, H. and MANWA, F., 2014. Poverty alleviation through propoor tourism: the role of Botswana forest reserves. Sustainability, vol. 6, no. 9, pp. 5697-5713. http://dx.doi.org/10.3390/su6095697.
MARTÍNEZ-HARMS, M.J. and BALVANERA, P., 2012. Methods for mapping ecosystem service supply: a review. Ecosyst. Serv. Manag., vol. 8, no. 1-2, pp. 17-25. http://dx.doi.org/10.1080/2 1513732.2012 .663792 .

MCFARLAND, B.J., 2018. Conservation of Tropical Rainforests. Springer. Payments for Ecosystem Services, pp. 337-429. http://dx.doi. org/10.1007/978-3-319-63236-0_11.

MILDER, J.C., SCHERR, S.J. and BRACER, C., 2010. Trends and future potential of payment for ecosystem services to alleviate rural poverty in developing countries. Ecology and Society, vol. 15, no. 2, pp. ‥ http://dx.doi.org/10.5751/ES-03098-150204.

MILLENNIUM ECOSYSTEM ASSESSMENT - MEA, 2004. Ecosystems and human well-being: synthesis. Island, Washington: Island Press.

MOONEY, H.A., EHRLICH, P.R. and DAILY, G.E., 1997. Ecosystem services: a fragmentary history. Nature's Services: societal dependence on natural. Ecosystems, vol. 7, pp. 11-19.

RODRÍGUEZ-ROBAYO, K.J. and MERINO-PÉREZ, L., 2018. Preserve and produce; experience in implementing payments for environmental services in two indigenous communities in the Northern and Southern ranges of Oaxaca, Mexico. Journal of Sustainable Forestry, vol. 37, no. 5, pp. 504-524. http://dx.doi. org/10.1080/10549811.2018.1432363.

SNYMAN, S., 2017. The role of private sector ecotourism in local socio-economic development in southern Africa. Journal of Ecotourism, vol. 16, no. 3, pp. 247-268. http://dx.doi.org/10.10 80/14724049.2016.1226318.

VO, Q.T., KUENZER, C., VO, Q.M., MODER, F. and OPPELT, N., 2012. Review of valuation methods for mangrove ecosystem services. Ecological Indicators, vol. 23, pp. 431-446. http://dx.doi. org/10.1016/j.ecolind.2012.04.022. 